\title{
De nouvelles questions essentielles en radioprotection
}

\author{
Mots clés : Fukushima / accident nucléaire / crise / COVID / radiobiologie
}

Un an déjà et l'évolution de la pandémie de COVID-19 qui continue de submerger le monde entier donne une nouvelle tournure aux défis de crise que nous avons déjà abordés dans des éditoriaux précédents. De nombreuses nouvelles questions essentielles doivent encore être anticipées en radioprotection, ainsi les articles portant sur ces sujets sont les bienvenus dans Radioprotection. Au travers de cet éditorial nous vous proposons d'en identifier quelques-unes.

La première question est celle de la qualité de la préparation à un accident nucléaire ou radiologique majeur. Les forces techniques et de la sécurité civile sont certainement bien entraînées pour une réponse rapide sur la base des plans d'urgence. Cependant, la pandémie de COVID et les accidents nucléaires antérieurs ont montré que les crises ont bien d'autres dimensions à prendre en compte pour s'y préparer: une durée prolongée en mois ou en années, le partage de données scientifiques précises et validées, la logistique et le management des chaînes d'approvisionnement, et bien sûr l'information et la communication. Les media et les réseaux sociaux aiment les controverses et font leur miel des opinions individuelles de toutes sortes de (non) spécialistes; les débats qu'ils capturent et mettent en exergue sont souvent loin d'être équitables et peuvent créer beaucoup de confusion au sein de la population tout en mettant une pression immense et délétère sur les autorités. La gestion des incertitudes scientifiques dans le domaine de la décision devrait être examinée tout particulièrement (Perko et al., 2020).

Du fait d'une reconnaissance et de supports financiers et en ressources humaines insuffisants, les radiobiologistes n'ont pas les moyens de produire les données scientifiques qui permettraient de répondre à toutes les questions soulevées par les expositions des patients, de la population, des travailleurs et de l'environnement aux rayonnements ionisants, mais aussi de participer à un débat constructif à propos des effets des faibles doses (la majorité des expositions) (Bourguignon, 2020).

La dernière publication de Radioprotection dédiée aux anniversaires de Tchernobyl et de Fukushima soulève de nombreuses interrogations psycho-sociales liées aux situations accidentelles, indiquant l'importance de leur prise en compte (Bertho et Tsubokura, 2020). La confiance par exemple est au cœur de la gestion de telles situations. Il est primordial que les populations aient confiance à la fois dans tous les aspects techniques et leurs résultats (mesures...) mais aussi, et c'est un prérequis, dans les techniciens qui les gèrent et dans les autorités qui décident in fine (Lochard et al., 2020). Un retour d'expérience à méditer !

Les concepts de risque et de danger doivent être explorés davantage car ils sont au cœur des processus de décision et, en conséquence, déterminent l'allocation des budgets, incluant ceux de la recherche et les ressources humaines (Thellier, 2019). La perception appropriée par la population des risques et des dangers fait bien sûr partie de la confiance comme indiqué ci-dessus. Les rayonnements ionisants sont-ils dangereux? Les expositions aux rayonnements ionisants présentent un risque : quel est le danger réel de telles expositions? Tout dépend des situations d'exposition et de leurs paramètres spécifiques. Les modèles qui ont été utilisés jusqu'ici sont trop simples parce qu'ils ne prennent en compte seulement qu'un petit nombre de paramètres. Par exemple, nous manquons d'évaluations appropriées du risque des expositions médicales pour chaque organe. Nous ne prenons pas en compte la réponse individuelle comme part de la médecine personnalisée qui est reconnue aujourd'hui comme une clé de la prise en charge appropriée des patients. Cela semble être vrai également pour la réponse individuelle à l'infection SARS-Cov2. Donc l'épidémiologie moléculaire développée sur la base de bio-marqueurs est une priorité.

Gouverner, c'est prévoir. Aussi, c'est notre devoir et notre responsabilité d'essayer d'indiquer quelles sont les questions critiques. C'est ce que j'ai essayé de faire avec quelques exemples dans cet éditorial, mais la science progresse seulement si le débat est serein et équitable. Vous êtes donc invités à y contribuer en nous adressant vos points de vue et vos articles.

\section{New critical questions in radiological protection}

\author{
Keywords: Fukushima / nuclear accident preparedness / crisis / COVID / radiation biology
}

One year later, the poor evolution of the COVID-19 pandemic overwhelming the whole world gives a new twist to the challenges of crisis we already examined in previous editorials. There are many new critical questions that need to be anticipated in radiological protection and we welcome papers on these issues. We would like to address a few of them in this editorial.

The first question deals with the quality of our preparedness to a major nuclear/radiological accident. Technical and civil security forces are certainly well trained for a prompt response on the basis of emergency plans. However, the COVID pandemic 
and previous accidents have shown that crisis have many other dimensions to be taken into account as part of preparedness: a time scale of months or years, the sharing of accurate and validated scientific data, the logistics and supply chain management, and indeed both information and communication. Media and social networks love controversies and make their fruits of individual opinions of all kind of (non) specialists; the debates they capture and highlight are often far from fair and may create a lot of confusion for the population and a tremendous and deleterious pressure on the authorities. The management of scientific uncertainties in the decision process should be especially examined (Perko et al., 2020).

Because of insufficient recognition and support in terms of finances and human resources, radiation biologists are not able to rapidly produce the vast amount of scientific data and the constructive debate, which are necessary to cope with all issues raised by the exposures to ionizing radiation of patients, population, workers and environment. The questions of the effects of low dose ionizing radiation need to be extensively addressed since the vast majority of exposures occur at low doses (Bourguignon, 2020).

Our last Radioprotection issue dedicated to Chernobyl and Fukushima anniversaries addressed numerous psychosocial issues related to accidental situations, indicating their paramount importance (Bertho and Tsubokura, 2020). The issues of confidence and trust need to be further addressed because they are at the heart of the good management of such situations. People need to have confidence regarding all technical aspects (measurements...) but they need to have trust in persons who are dealing with those technical aspects and in authorities who decide and manage, the latter being essential or even more a prerequisite to the former (Lochard et al., 2020). A return of experience to meditate!

The concepts of risk and danger need to be further explored because they are at the core of decision-making processes and consequently drive budget allocations including research and human resources (Thellier, 2019). The appropriate perception of risk and danger by the population is indeed part of the trust as indicated above. Are ionizing radiations dangerous? Exposures to ionizing radiation present a risk but what is the real danger of such exposures? It depends on the situations of exposures and on their specific parameters. The models which have been used so far are too simple because take into account only a small number of those parameters. For example, we are lacking of appropriate evaluations of the risk of medical exposures of each organ. We do not address the individual response as part of personalized medicine, which is recognized today as the key of the appropriate management of patients. This seems to be true for the individual response to SARS-Cov2 infection as well. Thus, molecular epidemiology developed on the basis of biomarkers is a priority.

To govern is to foresee. Thus it is our duty and our responsibility to try to indicate what the critical issues are. This is what I have tried to do with some examples in this editorial, but science progress only with a fair debate. Therefore, you are invited to contribute by sending us your views and papers.

\section{Références}

Bertho JM, Tsubokura M. 2020. Les dates anniversaires des accidents de Tchernobyl et de Fukushima : une évolution des centres d'intérêt dans la gestion post-accident nucléaire. [Chernobyl and Fukushima anniversaries: an evolution of what is at stake in post-nuclear accident management]. Radioprotection 55(4): 259-261.

Bourguignon M. 2020. Advocacy for a strong and sustainable support to radiation biology research in order to optimize radiological protection. Radioprotection 55(3): 159-162.

Lochard J, Ando R, Takagi H, Endo S, Momma M, Miyazaki M, Kuroda Y, Kusumoto T, Endo M, Endo S, Koyama Y. 2020. The post-nuclear accident co-expertise experience of the Suetsugi community in Fukushima Prefecture. Radioprotection 55(3): $225-235$.

Perko T, Benighaus L, Tomkiv Y, Wolf HV. 2020. Guidance on communicating about uncertainties in nuclear emergency management. Radioprotection 55(HS1): S169-S174.

Thellier S. 2019. Analyse des risques en radiothérapie. Partie 2 : Des modes de défaillance aux modes de réussite, un changement de paradigme. Radioprotection 54(1): 21-30.

Michel Bourguignon* Rédacteur en Chef

pr.michel.bourguignon@gmail.com 